\title{
Regulation of Law Enforcement in Prevention and Handling of Fire Forests in Environmental Hazards
}

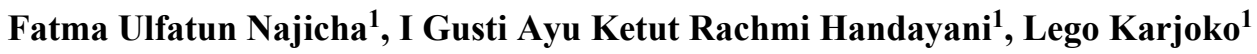 \\ ${ }^{I}$ Faculty of Law, Sebelas Maret University, Surakarta, Indonesia
}

\begin{abstract}
Forest is an ecosystem that provides oxygen, wood and a place to live for a variety of flora and fauna and places where interactions between plants (flora) and animals (fauna) are present. But in its development, environmental pollution carried out by most humans that can cause environmental damage, especially forests continue to occur with a variety of motives and types. Environmental damage is getting worse. This condition has directly threatened the life of ecosystems in the forest. One example of forest destruction by human activity is exploitation of natural resources by burning the forest. Forest fires have a wider impact on society, both local, national and international communities. Areas of Indonesia that have many forests with variations in community behavior are quite prone to fires. Knowledge about natural phenomena in the form of forest fires does need to be disseminated to the community. This is important, in order to avoid the impact of the danger caused by the fire.
\end{abstract}

Keyword: Law, Forest, Fire, Environmental Hazards.

\section{Introduction}

Forest is an ecosystem that provides oxygen, wood and a place to live for a variety of flora and fauna and places where interactions between plants (flora) and animals (fauna) are present. Forests also have natural resource potential including teak, meranti wood, sandalwood, acacia wood, fruits, honey, rubber, spices, rattan, sago, and others.

The importance of these resources is increasing because forests are a source of livelihood for many people. ${ }^{1}$ In Law Number 41 Year 1999 concerning Forestry, it is stated in Article 1 number 2 which reads: "Forest is a unified system in the form of an expanse of biological natural resources dominated by trees in their natural environment, which cannot be separated from one another". 2

\section{Corresponding Author:}

\section{Fatma Ulfatun Najicha}

Faculty of Law, Sebelas Maret University, Surakarta, Indonesia

e-mail: fatmanajicha_law@staff.uns.ac.id
But in its development, environmental pollution carried out by most humans that can cause environmental damage, especially forests continue to occur with a variety of motives and types. Environmental damage is getting worse. This condition has directly threatened the life of ecosystems in the forest. One example of forest destruction by human activity is exploitation of natural resources by burning the forest.

Forest and land fires basically can occur due to two factors namely, natural factors and human activity factors either intentional or unintentional. Although there is a natural factor in the form of El Nina that hits Indonesia every year, forest and land fires caused by natural processes are very small and rare events. This is due to the type of natural forests in Indonesia that fall into the category of tropical forests or wet rain forests so that the forest floor is always wet/moist. Conversely, $99 \%$ of forest fires are caused by human activity, both intentionally and unintentionally. Only $1 \%$ of them occur naturally. ${ }^{3}$

Knowledge about natural phenomena in the form of forest fires does need to be disseminated to the community. This is important, in order to avoid the impact of the danger caused by the fire. Even though 
forest fires are often called pure natural disasters, lately there has been a lot of human intervention in them. Thus, the discussion of the forest fire event widened by involving the phenomenon of social behavior. Forest fires have a wider impact on society, both local, national and international communities. Areas of Indonesia that have many forests with variations in community behavior are quite vulnerable.

\section{Literature Review}

\section{Environmental Legal Theory Review}

Definition of the Environment: The environment is a unity of space with all objects, power, conditions, and living things, including humans and their behavior, which affect nature itself, the survival of life, and the welfare of humans and other living things. ${ }^{4}$

Definition of Forest: According to forestry expert Dengler the definition of forest is a number of trees that grow on a large enough field so that temperature, humidity, light, wind, and so on no longer determine the environment, but are influenced by vegetation or new trees as long as they grow in a wide enough place and the growth is quite dense (horizontal and vertical).

According to Spurr the forest is considered as an alliance between plants and animals in a biotic association. This association together with its environment forms an ecological system where organisms and the environment influence each other in a complex energy cycle. The understanding of forests for scientists varies greatly according to scientific specifications. For example silvikur experts will provide a different understanding of the forest with forest management experts or ecologists.

Meanwhile, according to Law No. 41 of 1999 concerning forestry, forestry is a management system that has to do with forests, forest areas, and forest products that is held in an integrated manner. ${ }^{5}$ Forest is an ecosystem unit in the form of a stretch of land containing biological natural resources which is dominated by trees in their natural environment, which cannot be separated from one another. ${ }^{5}$ Forest area is a certain area designated and/or determined by the Government to be maintained as a permanent forest. $^{5}$

\section{Method}

The method used through literature review, from several journals which later the author uses as a basis, comparison, and complement to conduct a review in the field of Living Environment Law.

\section{Result and Discussion}

Ways to Prevent and Handle Forest Fires: Carter (2008) explains that in disaster management activities, pre-disaster aspects must be taken seriously. He divided into three activities namely (1) preventive, (2) mitigation, (3) preparedness. Maximizing all of these stages will determine success in preventing disasters. ${ }^{6}$

1. Preventive aspects: Preventive is an effort made so that disasters do not occur. Preventive activities that can be carried out are as follows:

1. Dissemination to the public, companies and all relevant parties that have the potential for forest fires.

2. Education and Counseling. Practically education and counseling is carried out by the leading elements of the task force institutions namely Babinsa, Village Officials, Agricultural Extension Officers, and SKPD.

3. Publication/Opinion through mass media. In addition to socialization and other actions, the task force by cooperating with various related parties continued to make publicity efforts about the dangers of the act of burning the forest either in the form of writing in print or in the mass media.

4. Technological innovation. Technological innovation, is specialized in the creation of certain technologies to support forest fire prevention efforts. This is based on the consideration that what is faced when forest fires are land conditions, weather, fire and human behavior.

2. Mitigation Aspects: Mitigation is an effort to minimize the impact of disasters. Some mitigation actions taken are:

1. Data collection and recording. This is intended to determine the distribution and potential risk of disasters, so that efforts can be made to minimize the impact that occurs.

2. Routine Patrol. Routine patrol activities are actions carried out by the task force on locations that are allegedly having the potential for forest fires. This patrol is carried out jointly, both from the task force and the community.

3. Preparedness: Preparedness is a quick step that 
must be taken to respond to a disaster. Some important things to do are:

1. Establish the Governor's Decree regarding the determination of the Task Force.

2. Conducting efforts to synchronize the task force's work program with other institutions in the task force's unit.

3. Establishment of Forest Fire Management Command Posts. The number of posts is adjusted to the existing area.

4. Construction of bore wells as a source of water for fire fighting.

5. Complementary infrastructure facilities to overcome forest fires.

Law Enforcement Arrangements in the Prevention and Handling of Forest Fires in Terms of Law Number 32 Year 2009 Regarding Environmental Protection and Management in Indonesia

Enforcement of environmental law is closely related to the ability of the apparatus and the community's compliance with applicable regulations. The following are some of the means of environmental law enforcement: ${ }^{7}$

a. Administrative Law Enforcement Facilities. The UUPPLH contains four types of administrative legal sanctions as stated in Article 76 paragraph (2), namely, administrative sanctions consisting of: Written reprimand, Government coercion, Freezing of environmental permits, and Revocation of environmental permits.

b. Means of Civil Law Enforcement. Civil law instruments can be used in the event of an environmental dispute arising from allegations of pollution and/or environmental damage. Enforcement of environmental law through civil law can be pursued through two channels, namely:

Court Track: Settlement of disputes through the courts is regulated in Article 87 to Article 92 UUPPLH-2009, namely to demand compensation and environmental restoration. There are several principles that must be considered by the panel of judges in examining the resolution of environmental disputes through the courts as formulated in Article 87 of the UUPPLH as follows: that causes harm to others or the environment is obliged to pay compensation and/or carry out certain actions. (2) Every person who carries out the transfer, alteration of the nature and form of business, and/or activities of a business entity that violates the law does not relinquish legal responsibilities and/or obligations of the business entity. (3) The court may determine forced payment of money on any late day for the implementation of court decisions. (4) The amount of forced money is decided based on statutory regulations. ${ }^{8}$

Out-of-court Paths: In Law No. 32 of 2009 concerning Environmental Protection and Management of the settlement of environmental disputes outside the court regulated in Article 85 states: ${ }^{9}$

\section{Settlement of environmental disputes outside the court is carried out to reach agreement on}

(a) The form and amount of compensation,

(b) Recovery actions due to pollution/damage,

(c) Specific actions to guarantee that pollution/or destruction will not recur, and/or

(d) Actions to prevent negative impacts on the environment.

2. Settlement of disputes outside the court does not apply to environmental crimes as regulated in this Law.

3. In the settlement of environmental disputes outside the court, the services of mediators and/or arbitrators can be used to help resolve environmental disputes.

Criminal Law Enforcement Facilities: In Law Number 32 of 2009 concerning Environmental Protection and Management, environmental criminal provisions are regulated in Article 94 through Article 120. While for forest fires the criminal provisions are in Article 108 which states: Every person who burns land as referred to in Article 69 paragraph (1) letter h, shall be sentenced to a maximum imprisonment of 3 (three) years and a maximum of 10 (ten) years and a fine of no less than Rp.3,000,000,000.00 (three billion rupiah) and a maximum of Rp.10,000 .000,000.00 (ten billion rupiah). ${ }^{9}$

\section{Conclusion}

There are three activities to prevent and handle forest fires according to Carter (2008):

1. Preventive is an effort made so that disasters do not occur. 
2. Mitigation of efforts to minimize the impact of disasters.

3. Preparedness/preparedness is a quick step that must be taken to respond to a disaster.

Means of environmental law enforcement in terms of Law No. 32 of 2009 concerning Environmental Protection and Management, namely:

1. Means of Administrative Law Enforcement, administrative law sanctions as stated in Article 76 paragraph (2).

2. Means of Civil Law Enforcement:

(a) Court Track: Settlement of disputes through court is regulated in Article 87 through Article 92.

(b) Track Outside the Court: Settlement of environmental disputes outside the court is regulated in Article 85.

3. Means of Criminal Law Enforcement, the provisions of environmental crime are regulated in Article 94 to Article 120.

In the effort to prevent and deal with forest fires, active participation in control policies implemented by the government, plantation companies and the community is needed. Prevention efforts aim to reduce the impact of forest fires because these efforts are relatively easier and cheaper than having to overcome the impacts after a fire has occurred. Therefore, it needs a growing awareness from all groups who have a concern for the preservation of forests and the environment to understand that the issue of forest fires and other environmental damage has reached an alarming level.

\section{Conflict of Interest: Nil}

\section{Source of Funding: Self}

Ethical Clearance: Environmental Law of Reseach through Environmental to Prevent the Dangers of Environmental Hazards, Faculty Of Law Sebelas Maret University on 02-07-2020.

\section{Reference}

1. Dodi N. Hutan Bagi Ketahanan Nasional. Surakarta: Muhammadiyah University Press; 2005. 1 p.

2. Supriyadi BE. Hukum Agraria Kehutanan: Aspek Hukum Pertanahan Dalam Pengelolaan Hutan Negara. Jakarta: Rajawali Pers; 68-69 p.

3. Suryadi M. Upaya Penanganan Kejahatan Lingkungan Pem,bakaran Hutan dan Lahan Gambut di Sumatera 2004-2015. J Int Relations. 2017;3(2):75-8.

4. Gusti Ayu Ketut Rachmi Handayani I, Gunarto G, Mashdurohatun A, Gusti Putu Diva Awatara I, Najicha FU. Politic of legislation in Indonesia about forestry and the mining activity permit in the forest area of environmental justice. J Eng Appl Sci. 2018;13(6).

5. About Forestry. No. 41 Indonesia; 1999.

6. Wibowo KA. Manajemen Penanganan Kebakaran Hutan dan Lahan (Karhutla) Guna Peningkatan Ekonomi Kerakyatan. J Stud Sos dan Polit. 2019;3(1).

7. Wibawa AK. Penegakan Hukum Terhadap Tindak Pidana Pembakaran Hutan Guna Pembukaan Lahan (Perspektif Hukum Indonesia Dan Hukum Islam). Surakarta: Faculty Of law Muhamamadiyah Surakarta University; 2016.

8. Najicha FU. Politik Hukum Pada Pembetukan Produk Hukum Perundang-Undangan Kehutanan. Kebumen: Intishar Publishing; 2019. 60 p.

9. Law No. 322009 Concering Environmental Protection and Managemet. No. 32 Indonesia; 2009. 